\title{
RECONSTRUCTION OF THE QUATERNARY GLACIAL LAKES OF IRAN (QALA'EHCHAI BASIN OF ZANJAN PROVINCE)
}

\author{
JAFARI, GH. H. ${ }^{{ }^{*}}-$ MOHAMMADI, $\mathrm{H}^{2}$ \\ ${ }^{1}$ Department of Geography, Faculty of Humanities, University of Zanjan, Zanjan, Iran \\ (Phone: +98-24-3305-4176; fax: +98-24-3228-3201) \\ ${ }^{2}$ Masters of Hydrogeomorphology, University of Zanjan, Zanjan, Iran \\ (Phone: +98-918-647-8944) \\ *Corresponding author \\ E-mail: Jafarihas@znu.ac.ir; phone: +98-917-751-9227 \\ (Received $31^{\text {st }}$ May 2018; accepted $31^{\text {st }}$ Aug 2018)
}

\begin{abstract}
The essence of all external morphogenesis processes depends on the governing climatic conditions of the time. Evidence suggests that the climatic conditions of the world and, consequently, external morphogenesis processes have undergone changes throughout the life of the earth. There are Ushaped valleys, cirques, local names and lake evidence around the Qala'ehchai Basin, which can be a reason for the quaternary glacier process. The glacier process of the region is approved by evidence such as the cirques and snow-line. For identification of glacier cirques, curve of the values extracted from DEM and Pari topographic map of 1: 50,000 scale is used. The quaternary snow-line is obtained using two methods of Wright and Porter. To identify pseudo-cirques, allometric method for the three parameters of length (L), width (W) and height difference (A) of the cirque, linear regression analysis in Excel software, and lithology study of main cirques have been used. Based on the highest snow-line calculated by Porter method $(2425 \mathrm{~m})$, all the lakes are situated above the height of the quaternary water and the ice equilibrium line. Field evidence and lithology of the region indicate that glaciers that are originated from high altitudes and well fed enter marl deposits by exiting the igneous area and resistant sediments. Glaciers in marl sediments create U-shaped valleys with a linear flow. After the treatment of glaciers, the necessary conditions for the creation of lakes are provided. The granulometry of the sediment sample suggests that when the location of the sediment is closer to the bank of the lake, its profile is similar to lake sediments and when its location is far from the center or bank of the lake, its profile is somewhat between glacial-lake sediments.
\end{abstract}

Keywords: allometry, paleoclimate, granulometry, cirque, Ghezelowzan

\section{Introduction}

The essence of all external morphogenesis processes depends on the governing climatic conditions of the time. Evidence suggests that the climatic conditions of the world and, consequently, external morphogenesis processes have undergone changes throughout the life of the earth. The long-term climatic data of the regions as well as the tracing of geomorphic evidence of climate change have not only been a nodule to many of the problems regarding the how of past lives, but also have raised a radical transformation in sociologists' perception of the evolution of human societies and have called some of their definitive findings for a serious reconsideration (Ramesht, 2001). The morphological effects of very old climatic changes, with the exception of the quaternary, used in various issues of geology and old geography, are either lost or fossilized (Jedari Eyvazi, 2013). Quaternary is the fourth, last, and youngest period that is so short unlike other geological periods. The existence of multiple climatic changes has led to the importance of studying this period (Martin et al., 2008). The emergence of humans and the recurrence of glacial and inter glacial periods are two important features 
of the quaternary period; in this period, two different glaciers and inter glacial climates are dealt with (Seif and Abtahi, 2013). The quaternary period, which began with the advent of continental glaciers from the polar regions, ended with the melting of the continental glaciers. After that, the post-glacial period was replaced. In Iran, the beginning of the post-glacial period has been estimated to be 10,000 years ago (Zomorodiyan, 2012). At the end of the Ice Age, global changes were made in atmospheric conditions with the global retreat of ice-covered plates and glaciers. As a result of the warming of the air and the increase in evaporation in rainfall, most of the lakes, covering many plains and plain areas in the midst of the mountains and current desert areas of the planet were dried up (Klinsley, 2009). Some believe that these lakes are caused by a tensile regime after compression, another group attribute them to the anticline bending of the Mirror toward Masha, and eventually, some other consider nondomesticated births as their cause (Oskooi and Omidian, 2013). The size of the lakes and altitude of aridity and water equilibrium line during the quaternary have been a function of snow-line altitude and ice and water equilibrium line altitude (Ramesht, 2004). The snow line is a linear boundary above which snow does not change, i.e. the snow remains in a cumulative state for a long time and does not turn into water above this line (Chinn and Whitehouse, 1980). Aside from lakes that simultaneously remain with ice until the formation of a part of the coast, there are also lakes that are formed when the glacier or ice field decoys. Thus, water in the ditch creates a lake with the wall of valleys on the iceberg. These lakes are slightly filled up until they flow to the surrounding area from the lowest point (Gresswell, 1958).

During the glacial periods, the lower regions of the water and ice line equilibrium have had high rainfall and lower temperatures than the current conditions. Therefore, this positive equilibrium of water and water, resulting from the melting of upstream ice, caused the formation of lakes whose banks are known as the aridity and water equilibrium line (Abtahi, 2013). Existing evidence in nature show that the conditions governing the past climate differ from today. In addition to the climate, the conditions of dehydration and hydrological cycles in basins depend on the physiographies and geological conditions. River entry or discharge does not depend only on the climate of the region, but the position of the lake relative to the basin makes sense of the increase in the entry because nutrition and energy are meaningful when there is a life (Velayati, 1995). Hollows and lakes are the lowest part of the basin and planar surfaces that are the result of stagnant waters. In other words, lagoons, lakes, reservoirs and sedimentation mechanisms in them lead to the formation of smooth surfaces with fine texture (Ramesht, 2013).

In addition to the presence of U-shaped valleys, cirques and local names of the mountains such as the Gharghalan (Permanent snow) around the Qala'ehchai Zanjan Basin, which are evidence of the sovereignty of the quaternary glacial process, there is a lake called Khandaghlo that still retains its identity. In fact, this lake, with greater water in the past, is another reason for the governance of the morphogenesis system of the quaternary glaciers in the region. In addition to Khandaghlo Lake, the reflection of landforms with simple and sometimes closed contour lines along with convergent drains, single-point elevations and two-way drain in topographic maps with a scale of 1:50,000 was evidence of the abundance of such lakes in the past, which are now largely destroyed and have lost their independence. In addition to the climatic changes in the quaternary, the change in the level of Ghezelowzan, including the Qala'ehchai, and the dominance of backward erosion in the region has played an indelible role in the 
destruction of the lakes in the region. Investigation of this issue can be very important in introducing the region, which is likely to be called the Finland of Iran, and encouraging environmentalists, paleontologists and, in particular, paleoclimatologists for further study of the region.

\section{Literature review}

According to the studies of Russell (1889) and Longmore and Heijnis (1999) on the lakes of the past, lunar periods coincided with the ice age. Walter Goldthwait (1908) reconstructed extinct aqueducts and glaciated lakes in the Michigan Lake Basin and used field evidence, and concluded that in Michigan and Wisconsin, rock cuts at the current levels of Michigan lake are severe, but stretch of the old coastline, which was 5 to 25 miles further away from the current surface, is partially or completely destroyed. In a study entitled fluctuations and changes in the cold stages of large lakes, including Larness affected by the Agassis and Barlow ice currents, Lewis and Anderson (1989) concluded that during the second period of frost and after its end, ice currents caused the discharge of the lake from the frozen state and flooded with the flow of the glacier down the lake, increasing the flow velocity. Olvmo and Johansson (2002) evaluated the importance of stone and lithological structure in deep weathering before glaciation and glacial erosion on the landforms of the West Coast of Sweden using satellite imagery, accurate mapping and frequent field observations, and concluded that the direction of ice and pre-glacial landforms is aligned with the forms engraved on the rocks of the area. Glassera and Bennettb (2004) argue that landforms of glacial erosion are the basis of paleo glaciology. Cossart et al. (2008) analyzed the slope instability of the glaciers in the mountainous areas of the Durranz Basin, in southeastern France, using field evidence, geographic information system, and spatial pattern combination, and concluded that large stones in avalanche of rock are related to the stress of the pressure; these avalanches are due to the rock breaking during the glacial period, where rocks become unstable with the slope after the glaciation and appear as avalanches. Bao et al. (2009) studied coverage of surface tensile stresses in the past Neo-Proterozoic 2 ice lake in Svalbard. Sundal et al. (2009) explored the evolution of the ultra-glacial lake across the Greenland plate. Bajracharya and Mool (2009) discovered the behavior of glaciers and the explosion of lagoons in ice lakes in the study of glacial and ice lakes in the Nepalese region of Everest. Askari Chawardi (2009) investigated lake of the Jajrood valley during the quaternary period and concluded that one of the factors causing the formation of lakes is the transfer of glacial deposits in the quaternary period, their density at the margin of Jajrood valley, landslide occurrence during the glacial and tectonic periods. Bolch et al. (2011a) identified a dangerous ice lake in North Shian and concluded that climate change and global warming have the potential to create an increasing number of glacial lakes, and the flooding of these lakes also causes serious damages and risks. In another study, Bolch et al. (2011b) studied the evolution of ice lakes along the Hindu Kush mountain range between 1990 and 2009 using Landsat satellite imagery and concluded that in eastern Nepal, India and Bhutan, lakes are larger and more numerous; however, glacier in the Hindu Kush $(50 \%)$ and Karakorum (30\% contraction) is associated with the loss of ice in the western part of Hindu Kush Himalaya. With a study on the potential volume of the Himalayan lake flood based on satellite imagery, the angle of stagnation on the lake bank, and estimation of the volume of flood on more than 2000 lakes, Fujita et al. (2013) found that there are 794 lakes lacking Steep Lakefront Area; meanwhile, the volume of the lake was identified as 
10 million $\mathrm{m}^{3}$ of ice. Jananeh, and Rajabi (2016) studied the effects of the quaternary period on Iranian seas and lakes and found evidence that the sea and lake levels had been up and down during glacial quaternary periods. In addition, they asserted that changes in Iran's sea and lake levels during glacial periods are quite similar to changes in the global scale and that there is evidence of existence of lakes in today's deserts, but there are different views on their extent and depth. The glaciers are the origin of the formation of most lakes, and alone contribute to the formation of lakes more than any other factor. These types of lakes are not too deep and are caused by glacial factors. Kiani et al. (2016) assessed the ecological vulnerability of climate change in Abarkuh Basin, concluding that the change in the ratio of environmental parameters occurs during cooler periods and all of the thresholds of transit stability and general state of environmental systems are on the verge of collapse. Ghiyas Abadi et al. (2014) stated that Gohar Lake is the only mountainous lake with glacial Paternoster species in Iran. Entezari et al. (2015) studied the geomorphology of climate change in the Gorganroud Basin during the quaternary period and compared two maps of the current and quaternary periods, showing a temperature difference of $9.4^{\circ} \mathrm{C}$. They also showed that the cool and humid climates are in the fourth quarter. Studies on the Paleolithic in Iran go back to the work of French Democrats (1907); while discovering some rocky devices in the Pleistocene sediments in the Caspian Basin, it is stated that Iran was covered by mountain glaciers and lakes during this period. Some of the Iranian researches on glaciation and glaciers include Ramesht (2004), Tahoni (2004), Yamani et al. (2007), Rezvani et al. (2010), Ghahroudi Tali (2011), Amirahmadi et al. (2011), Abtahi (2013), Parizi et al. (2013), Jafari and Asghari Serkansrudi (2014), and Shamsipour et al. (2015).

\section{Materials and methods}

\section{Study area}

Several lakes in the quaternary have been created by glaciers or glacial treatment. These lakes have been created by rill erosion or sedimentation of glaciers or due to the creation of a moraine dam. The Ombilics and the Verrous are also places that have spawned in glacier valleys, creating permanent and temporary lakes. Posture, on the one hand, and proper rainfall feeding, on the other hand, have led the glacier cirques to become small and scattered lakes so that the high cirque lakes are the result of the melting of the upstream snow and downstream cirque lakes are due to the overflow of the upper cirque lake (Derruau, 2011). The Qala'ehchai Basin is one of the regions in Iran that has well retained evidence of glacial lakes. The Qala'ehchai is one of the subbasins of Ghezelowzan Basin, originating from the northeastern slope of Belquis Mountain and joining Ghezelowzan from the western-eastern direction near the village of Moshampa. The Ghezel Owzen joins the Caspian sea through Sefidrud, and pouring into the lake of the Manjil dam. Khandaghlo Lake is one of the lakes alive in Zanjan Province in highlands near Belquis Mountains. Basin area is over $618,400 \mathrm{~m}^{2}$ and has a length of over $3150 \mathrm{~m}$. Its maximum depth is 5-6 m and its average depth is $1.5 \mathrm{~m}$. The main lithology of deposits is marl. The altitude of Khandaghlo Lake is $1600 \mathrm{~m}$ and it is under the influence of the adjacent glacial system. The lithology and climatic conditions of the Qala'ehchai Basin have led to the formation of closed basins, some of which have been ruptured and destroyed. However, they can have water for some times of year through proper management. The geographical area of the Qala'ehchai Basin is located about $47^{\circ} 15^{\prime}$ to $47^{\circ} 30^{\prime}$ east and $36^{\circ} 45^{\prime}$ to $37^{\circ}$ north latitude. The total area is $780 \mathrm{~km}^{2}$ 
and its average height is $2220 \mathrm{~m}$ above sea level. This basin is limited from the west to Takab Provance, from the east to Hesar-Moshampa Department, from the south of Mahneshan Township, and from the north to Miyaneh Township (Fig. 1). This basin is a part of the Khoy-Mahabad Zone (Nabavi, 1976) in terms of geological structure and it is located in the intersection of Sanandaj-Sirjan, Alborz-Azerbaijan and Central Iran zones. This area is composed of metamorphosed rocks of schist, marl, gneiss and amphibole, with the northwest-southeast trend in the middle sections of the Ghezelowzan Basin. The higher altitudes are $3330 \mathrm{~m}$ in Belquis Mountain and $3208 \mathrm{~m}$ in Ghebleh Dagh Mountain. These rocks are directly covered by non-sorting OligoMiocene sediments. It seems that metamorphic rocks of the Precambrian to Paleozoic period from the second to the middle of the terrain constitute high altitudes with no sediments on them, a slight potential deposition may have been demolished due to high altitude and erosion. Generally, the rocks in the studied area are Precambrian metamorphic rocks, Late Precambrian sedimentary rocks, previous Cambrian and Cambrian-Ordovician, Paleozoic metamorphic rocks, Diorite intrusive masses, Granodiorite and Gracie volcanoes, Oligo-Miocene volcanic rocks, Pliocene, and quaternary sediments from below upwards, respectively (The Iran Geological Survey).

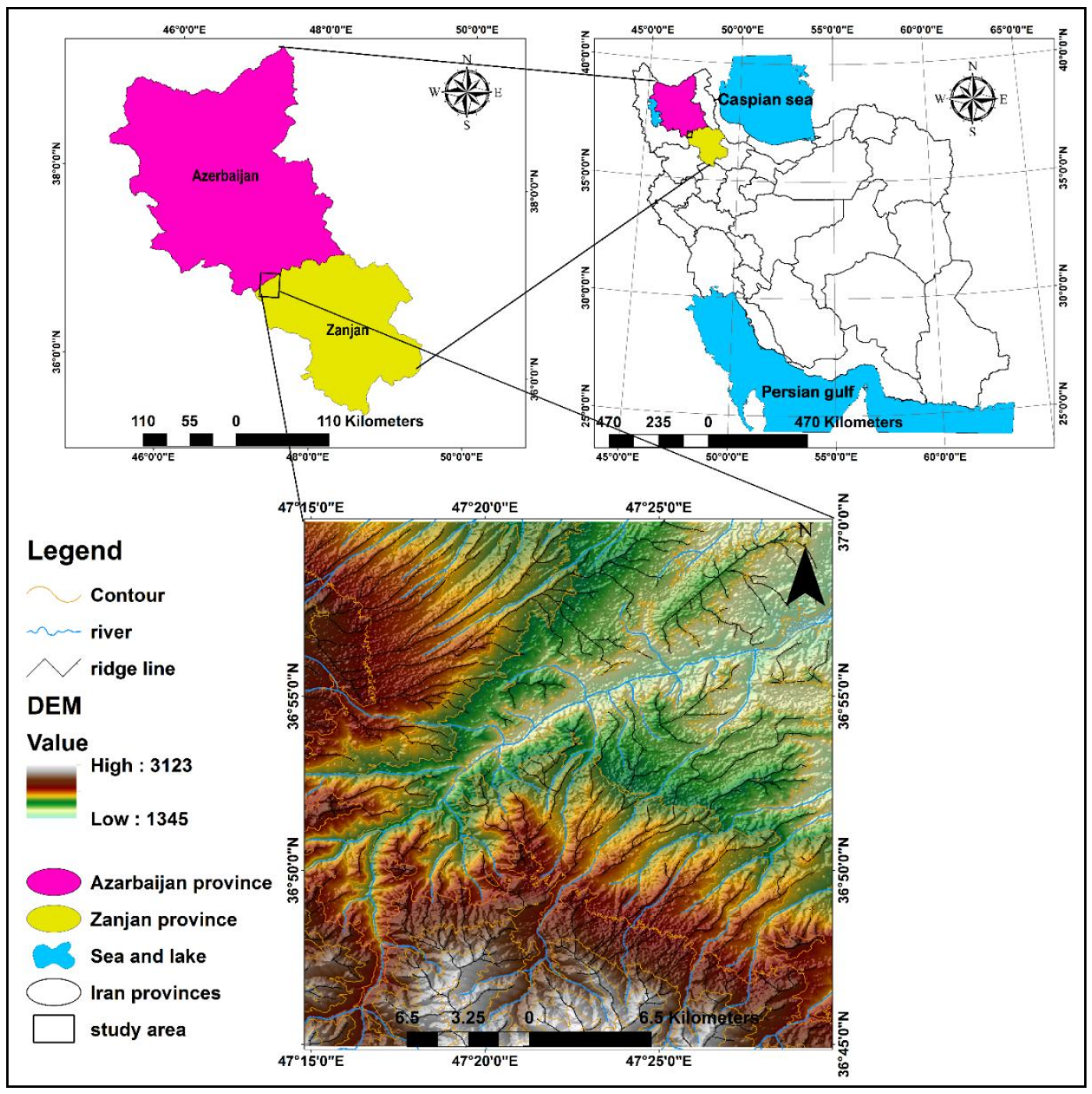

Figure 1. Map of the study area 
Extrusive basalt disturbs the region's morphology and is resistant to erosion, which does not easily react to corrosive factors. It is unevenly distributed on the marl and gypsum sandstone, periodic andesite lava of marl, and red sandstone with gypsum, been greatly expanded in the southwest region with layers of the travertine spring deposited horizontally. The sediments of this unit can be considered equivalent to the upper red formations in Qom area. It is also distributed on the periodic conglomerate unit of marl and sandstone with gypsum horizons, being expanded to the west-southwest of the basin. Geomorphologic and hydrological conditions of the area, such as the existence of marl between the sandstone and conglomerate layers in vast areas of the basin, together with the low topographic conditions reflected in topographic maps of 1:50,000 scale farther away from the current river bed indicate that many parts of the region have had more equilibrium conditions during the quaternary. Disturbances of faults and over thrusts are seen in Takht-e-Solayman Mountains and west of Qala'ehchai. These faults are perpendicular to the Qala'ehchai River. The most important fracture in the GhirgehChahar Tagh fault is in the north west-southeastern trend that crosses the middle sections of the area (Fig. 2).

\section{Methods}

To study quaternary changes, Digital elevation model (DEM) was extracted from satellite images with resolution $30 \mathrm{~m}$ from ASTER of the year 2017. The topography layer was prepared using ARC GIS software. The glacial process of the region was proven by evidence such as cirques and snow-line frontiers. For identification of glacier cirques, curve of the values extracted from DEM and Pari topographic map of 1: 50,000 scales is used. The curved line indicates the glacial process that is reflected as a fan in the impassable valleys. Also, the quaternary snow-line was obtained using Wright and Porter methods. The method of elevation of the cirques floor is one of the five methods Porter has proposed to reconstruct the equilibrium line at low latitudes. The use of this method depends on the number, geographic direction, the altitude classes and the percentage of cirques. Floor altitudes were measured as the single lowest DEM grid cell within each cirque. Latitude and longitude were measured from the centre point of each cirque; and the aspect was measured as the outward direction of each cirque's median axis (Evans, 1977; Evans and Cox, 1995; Barr and Spagnolo, 2015). In Wright's method, by multiplying the number of glacier cirques in 0.6 , the number of rows of cirques in descending from in terms of height is obtained. This altitude is the height of the quaternary equilibrium line altitude (ELA). This method estimates ELA by determining the location and altitude of $60 \%$ of cirques above the line. For estimating ELA, the altitude of identifying cirques is sorted based on descending order. Then the number of cirques is multiplied to $60 \%$ (Eq.1). The gained number represents a numerical line of cirques in which ELA is located. In the following, $\mathrm{X}$ shows the number of rows and $\mathrm{N}$ is cirques number.

$$
X=N \times 0.6
$$

The existence of pseudo-cirques led to the determination of the three parameters of length (L), width (W), a height difference of cirque (A) through allometric method and linear regression analysis in Excel software and lithologic study of main cirques in order to determine the correct snow-line. 


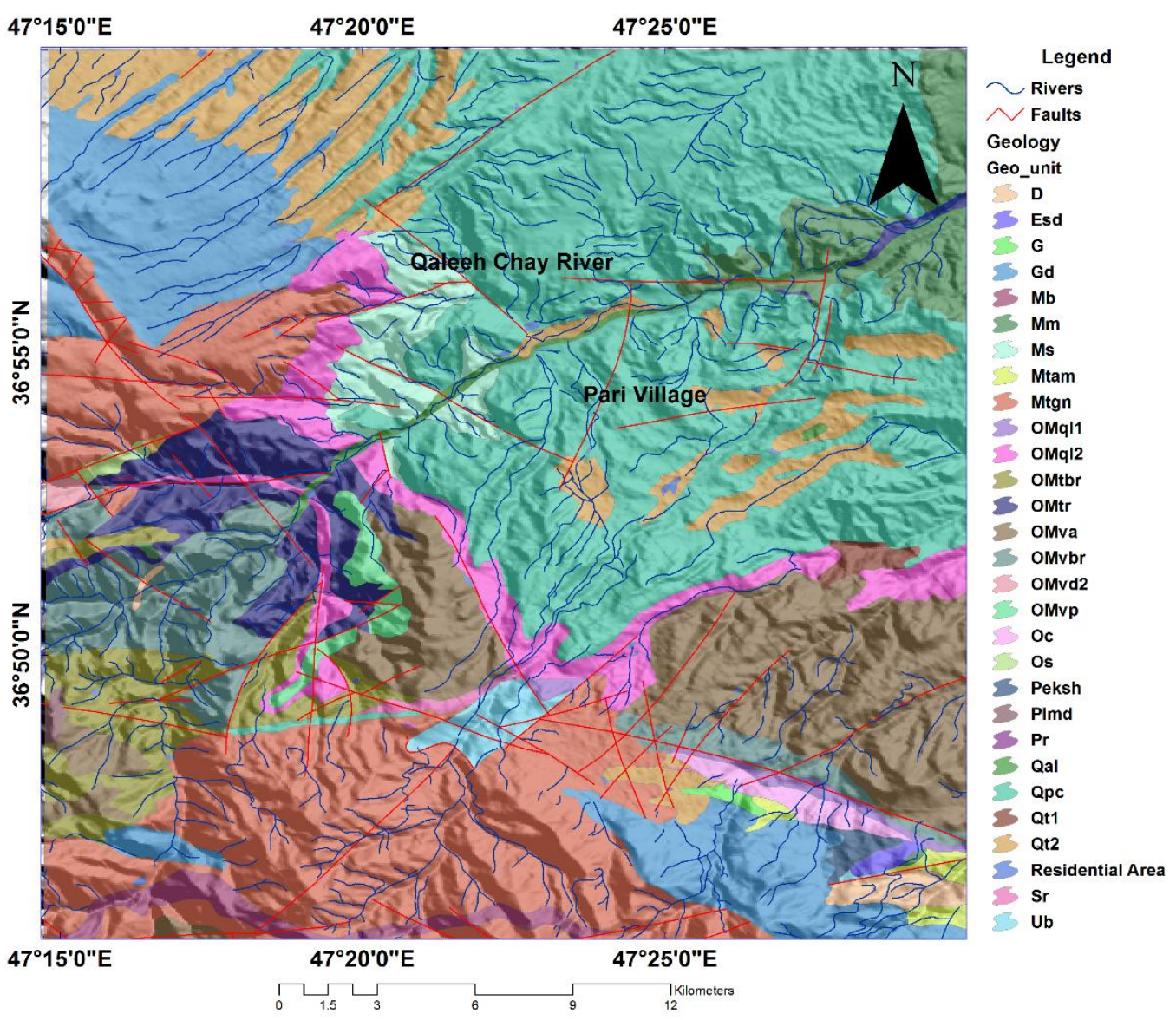

Figure 2. Geologic maps of Qala'ehchai Basin. D = Quartzdiorite, diorite, gabbro. Esd = Grey dolomite with black landed there. $G=$ Granite. $G d=$ Grey granodiorite, granodiorite gneiss. $M b=$ Marble. $M m=$ Marl and sandstone with gypsum beds. $M s=$ Alternation of red marl and sandstone. Mtam = Amphibolite with marble intercalations. Mtgn = Alternation of gneiss, marble and amphibolite. Omql1 = Massive limestone, fossiliferous, cream to light grey. Omql2 = Cream, thick bedded to massive limestone (Aquitanian-Burdigalin) with yellowish green marly intercalations. Omtbr $=$ Hyaloclastic luff breccia, luff and sandy tuff, thick bedded to massive, grey-green. Omtr = White to pink pernicious luff breccia. Omva = Grey brown and violet porphyritic andesitic lava. Omvbr = Andesitic volcanic breccia and conglomerate, hyaloclastic tuff breccia. Omvd $2=$ Pink dacitic and jgnimbritic lavas and related tuffs. Omvp = Andesitic pillow lava. Oc $=$ Red conglomerate and sandstone. Os $=$ Red sandstone and marl. Peksh = Alternation of micaschist and quartzite grey - green. Plmd = Microdiorite rnicromonzonite subvolcanic bodies. Diabasic dykes. $\mathrm{Pr}=$ Volcanic glass (perlite).

$Q a l=$ Recent alluvium. $Q p c=$ Loose clay-cemented polygentic conglomerate. $Q t 1=$ Old terraces and high gravel fans (Gravel, sill and clay). Qt2 = young terraces and low gravel fans ( sand, ails and clays). Residental area = village and city. $\mathrm{Sr}=$ Metamorphosed ultramafic mafic lava flow (Komatiile). Ub = Metamorphosed ophiolitic rocks (serpentine, diabase and basaltic lava)

Geologic maps of the Mahneshan at 1: 100,000 scales were used. The topography is reconstructed with respect to the equilibrium environments in the topographic maps. Two-way drains and single-point elevations along with closed contour lines on topographic maps indicate the abundance of lake in the past. Using the pixel to code software, the areas where such evidence was seen were digitalized and the past 
topography of the region was reconstructed with the help of digitalized data in the Surfer software through the Kriging interpolation. The watershed and basins were drawn and lake area was reconstructed with Generate watershed extension in the Global Mapper software. The converging radial drainage channels represent a lake. To verify and document the previous lakes, sediment sampling was implemented in areas where there was the possibility of lake in the simulation of previous topography. In this way, sediment samples were taken from places where there were old terraces. In the laboratory, the granulometry operation was carried out through the following steps: 1Sample washing; 2- Sample placement in the oven device for $24 \mathrm{~h}$; 3- Detachment of dried sediment after the operation of shiker for $15 \mathrm{~min}$; 4- Weighing each of the remaining samples in each of the sieve's pieces; 5- Plotting the frequency table based on the obtained data; and finally, 6- Drawing the cumulative curve graph in Excel software and matching each of the obtained graphs with the curve of the lake sediment.

Quantitative relationships were applied to the data resulting from the granulometry of the sampled sediments. Using these relationships, sediment status was analyzed in terms of standard deviation ( $\sigma \mathrm{i})$, mean size (Mz), skewness (SKi) and kurtosis (KG). The final analysis of the data was done according to the values of Table 1. In addition, the final analysis was done by comparing the data of other samples with the data's Peri Lake sediment sample, the only live evidence from past lakes.

Table 1. Descriptive measures of grain size distribution (Ward, 1957; Obinegbu et al., 2013)

\begin{tabular}{|c|c|c|}
\hline Parameters & Formulas & Verbal terms \\
\hline Mean size $(\mathrm{Mz})$ & $\mathrm{Q} 16$ + Q50 + Q84/ 3 & $\begin{array}{c}\mathrm{Mz}=-1--2 \text { granule } \\
0--1 \text { very coarse sand } \\
0-1: \text { coarse sand } \\
\text { 1-2: medium sand } \\
\text { 2-3: fine sand }\end{array}$ \\
\hline Standard deviation $(\sigma i)$ & $\mathrm{Q} 84-\mathrm{Q} 16$ / 4 + Q95 - Q5 / 6.6 & $\begin{array}{c}\sigma \mathrm{i}=>0.35: \text { very well sorted } \\
0.35-0.50: \text { well sorted } \\
0.50-1.0: \text { moderately sorted } \\
\text { 1.0-2.0: poorly sorted } \\
\text { 2.0-4.0: very poorly sorted } \\
\text { < 4.0: extremely poorly sorted }\end{array}$ \\
\hline Skewness (SKi) & $\begin{array}{c}\mathrm{Q} 16+\mathrm{Q} 84-2(\mathrm{Q} 50) / 2(\mathrm{Q} 84-\mathrm{Q} 16)+ \\
\mathrm{Q} 5+\mathrm{Q} 95-2(\mathrm{Q} 50) / 2(\mathrm{Q} 95-\mathrm{Q} 5)\end{array}$ & $\begin{array}{c}\text { Ski => +1.0-+0.3 very positively skewed } \\
0.3-0.1: \text { positively skewed } \\
0.1-(-0.1): \text { symmetrical skewed } \\
-0.1-(-3.0): \text { negatively skewed } \\
-0.3-1.0: \text { very negatively skewed }\end{array}$ \\
\hline Kurtesis (KG) & Q95-Q5/2.44 (Q75-Q25) & $\begin{array}{c}\mathrm{KG}=><0.67 \text { very platykurtic } \\
0.67-0.90 \text { platykurtic } \\
0.90-1.11 \text { mesokurtic } \\
1.11-1.50: \text { lepokurtic } \\
1.50-3.00: \text { very lepokurtic } \\
>3.00 \text { extremely lepokurtic }\end{array}$ \\
\hline
\end{tabular}

\section{Results and discussion}

Many of the lakes that were in the glacial period have been torn apart after being overflowed or absorbing large quantities of water, and have been ruined by the dominance of various erosions. One of the major factors affecting the destruction of 
lakes is the change in the base level that results in the collapse of the river system, causing phenomena such as gullies. These gullies or so-called gully erosion snatches and captures the rivers. There are many other lakes that have not been completely destroyed or eroded. There is evidence around these basins indicating that they were lakes in the quaternary. Among the evidence that can be seen in the field vision is the alluvial terrace left by the lake after passing wet and dry periods. Based on their own characteristics, such as texture, structure, color and thickness, these terraces are of particular features. Existence of other evidence on topographic and geological maps is of great help in identifying the lake. These evidences are as follows (Fig. 3): 1. Closed and hole-like contour lines; however, these holes should be detected from the contour line of mountain peaks and volcanoes; 2 . Rivers that have been deformed to two-way canals; 3 . Single altitude points in the between contour line; 4 . To entity material of sediments of past terraces in geological maps.

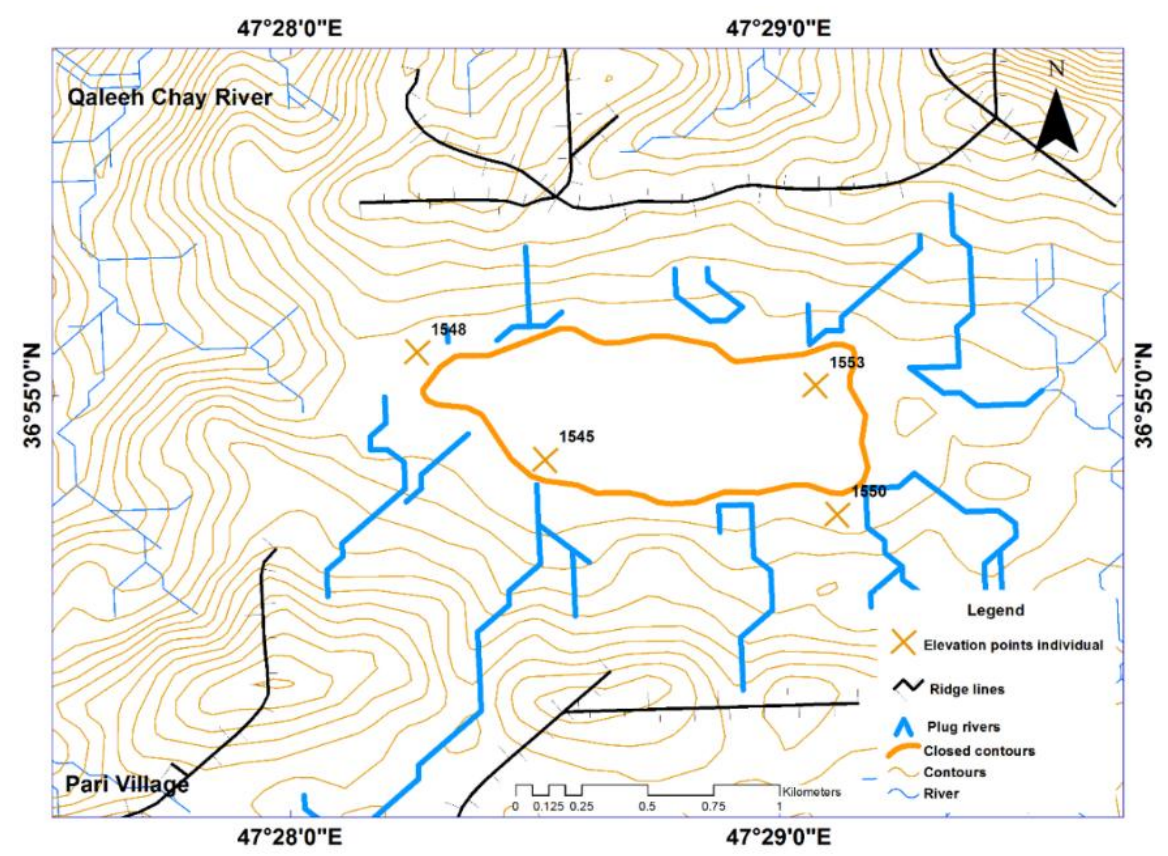

Figure 3. Evidence of the existence of a lake on a topographic map

\section{Allometry of the cirques}

Detecting glacial effects in mountainous areas is one of the important tasks to be achieved by the remaining evidence. The most important pattern resulting from glacial erosion is the glacial cirques. From a spatial point of view, any hole-like area holds snow and is called a snow house. However, not all holes and amphitheatres are glacial cirques. On the other hand, it is necessary to consider several factors including lithology. Effects of cirques do not remain in loose sediments such as marl, clay and conglomerate for a long time, and they are pseudo-cirques that cannot be attributed to the cirque. For a better study of the cirques and separation from pseudo-cirque, the cirque allometry, i.e. obtaining parameters such as length, width, floor area, height of the peak overlooking the cirques, and slope of the cirque, is done. Usually, in a cirque space, there is a high correlation between the special parameters of the cirque. Otherwise, correlation is reached to higher than $50 \%$ by eliminating liars that are 
pseudo-cirques. After finding glacial cirques, their height was accurately calculated. The cirques were sorted by height in a descending order and the total number of cirques was multiplied by 0.6 , and the altitude of the number of the row obtained in the descending order was considered as the quaternary snow-line elevation. Accordingly, the snow-line of the study area was $2364 \mathrm{~m}$ above sea level. The corrected snow-line after allometry of glacial cirques also averaged $2354.7 \mathrm{~m}$. Snow-line correctly to suit the paper (Seif and Ebrahimi, 2014) was a linear relationship between the length, width and height of the cirques confidence R2 above $90 \%$ for solidarity cirques evaluated. Using the cirque floor method of Porter, the frequency of the cirques was determined in geographical directions and snow-line elevation was obtained after performing the necessary analyses. Snow-line elevation was $2354.7 \mathrm{~m}$ above the sea level in the Wright method and it was $2425.12 \mathrm{~m}$ in Porter's method, with a difference of $70 \mathrm{~m}$ (Table 2) (Fig. 4).

Table 2. Data Porter's method for determining snow-line

\begin{tabular}{|c|c|c|c|c|c|c|c|c|c|c|}
\hline \multirow[b]{2}{*}{$\begin{array}{c}\text { Elevation } \\
\text { classes* }\end{array}$} & \multirow[b]{2}{*}{$\begin{array}{c}\text { Cirque } \\
\text { abundance }\end{array}$} & \multicolumn{8}{|c|}{ Directions } & \multirow[b]{2}{*}{$\begin{array}{l}\text { Cirque } \\
\text { percent }\end{array}$} \\
\hline & & North & $\begin{array}{c}\text { North } \\
\text { East }\end{array}$ & East & South East & South & $\begin{array}{l}\text { South } \\
\text { West }\end{array}$ & West & $\begin{array}{l}\text { North } \\
\text { West }\end{array}$ & \\
\hline $1600-1200$ & 7 & 3 & 1 & - & 2 & - & - & - & 1 & 4.96 \\
\hline $2000-1700$ & 11 & 2 & 2 & 4 & 1 & - & - & 1 & 1 & 7.8 \\
\hline $2300-2100$ & 33 & 4 & 11 & 11 & 3 & - & 2 & 1 & 1 & 23.40 \\
\hline $2600-2400$ & 53 & 3 & 18 & 17 & 8 & 2 & 1 & 2 & 2 & 37.58 \\
\hline $3300-2700$ & 37 & 4 & 11 & 15 & 3 & - & 1 & 2 & 1 & 26.24 \\
\hline Sum & 141 & 16 & 43 & 47 & 17 & 2 & 4 & 6 & 5 & 100 \\
\hline $\begin{array}{c}\text { Average } \\
\text { height (m) }\end{array}$ & - & 2469.6 & 2337.9 & 2290.4 & 2479.64 & 2651.75 & 2724 & 2473 & 2369.8 & 2477.01 \\
\hline Facade (M) & - & 2559 & 2100 & 2519 & 1600 & 2752 & 2699 & 2732 & 2448 & 2425.12 \\
\hline $\begin{array}{l}\text { Opposite } \\
\text { poles } \\
\text { Cirque }\end{array}$ & & & & & $\begin{array}{l}\text { Amounts } \\
\text { Facade }\end{array}$ & & & & & 2559 \\
\hline $\begin{array}{l}\text { Equator } \\
\text { opposite } \\
\text { cirque }\end{array}$ & & & & & $\begin{array}{l}\text { Amounts } \\
\text { Facade }\end{array}$ & & & & & 2752 \\
\hline$\triangle E L A$ & & & & & $\begin{array}{c}\text { The } \\
\text { difference } \\
\text { between the } \\
\text { two domains }\end{array}$ & & & & & 193 \\
\hline $\begin{array}{l}\text { Snow-line } \\
\text { altitude }\end{array}$ & & & & & & & & & & 2425.12 \\
\hline
\end{tabular}

Given the linear relationship of temperature and height, the current temperature of these elevations can be estimated (Eq. 2).

$$
Y=-0.0045 X+18.06 \quad R^{2}=0.84
$$

In Equation 2, $\mathrm{X}$ is the height and $\mathrm{Y}$ is the estimated temperature for the current situation. Based on Equation 2, the current snow-line temperature is 7.46 using the Wright method and is $7.15^{\circ} \mathrm{C}$ using Porter's method. In subsequent calculations, the 
average temperature is considered to be 7.3. In fact, the minimum quaternary temperature reduction is considered to be $7.3{ }^{\circ} \mathrm{C}$.

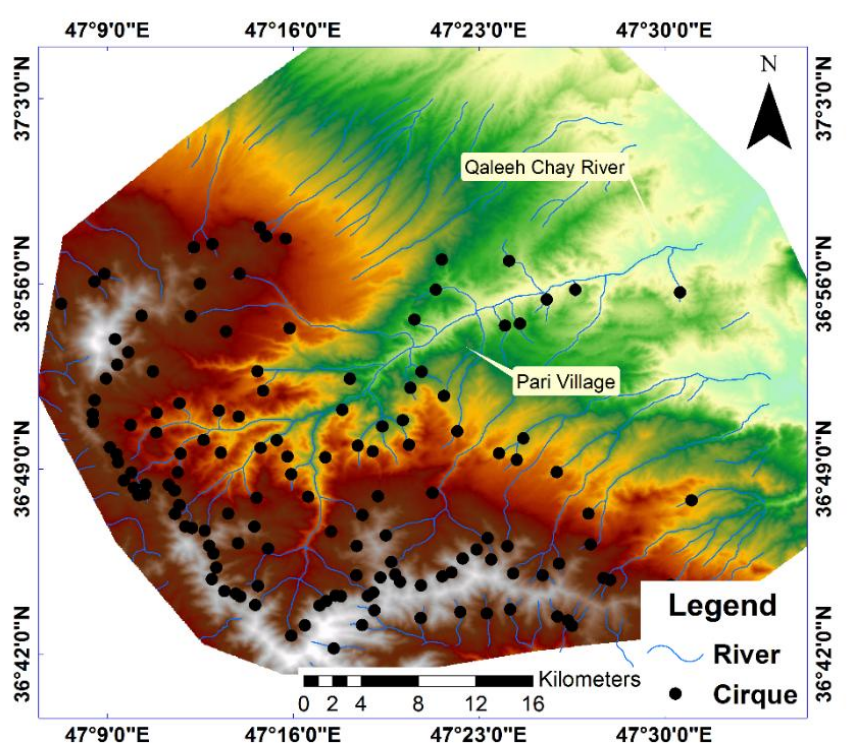

Figure 4. Scattering of glacial cirques in the study area

\section{Topographic reconstruction}

The base level of Ghezelowzan River Basins and Sub-basins has considerably changed during the quaternary period. The base level changes basically led to the formation of various morphogenesis and processes, such as the capture phenomena. In the capture of a river, the river changes into another direction. Stream capture, river capture, river piracy or stream piracy is a geomorphological phenomenon occurring when a stream or river drainage system or watershed is diverted from its own bed, and flows instead down the bed of a neighbour stream. The changes in the base level of Ghezelowzan River were about 200 m (Fig. 5). Base level changes have changed the flow of river processes and the dominance of gully erosion. The domination of gully erosion in the headwaters of the basin changes the alluvial process in pluvial process. In clay and silt lands in stagnant waters, in the case of running water, the form of the contour lines is expressed as the claw sinusoidal. Depending on the degree of erosion of these surfaces, the sinusoidal contour lines tend to be medial and claw-like. On topographic maps, wherever the gradient of the earth is very low, single elevation points are plotted instead of plotting the contour lines. This indicates that the intended level has evolved in the process of functioning of stagnant water. This is because very slow slopes have been developed in the bed of stagnant waters and secondly, the sediments will be fine-grained since the lake's environments and stagnant waters are low-energy and provide conditions for sedimentation with a diameter of less than $0.15 \mathrm{~mm}$. In addition, convergent radial channel lines at these levels suggest the existence of past lakes. Drawing profiles (Fig. 6) Perpendicular to Qala-ehchai River on the left and right banks of the river showed that there were terraces of the same height with common ground, common slope and common morphology. Placing the longitudinal and transversal profiles on the region and the probability of existence of lake focuses attention on the terraces of the same height on both sides of the Qala-ehchai River. 


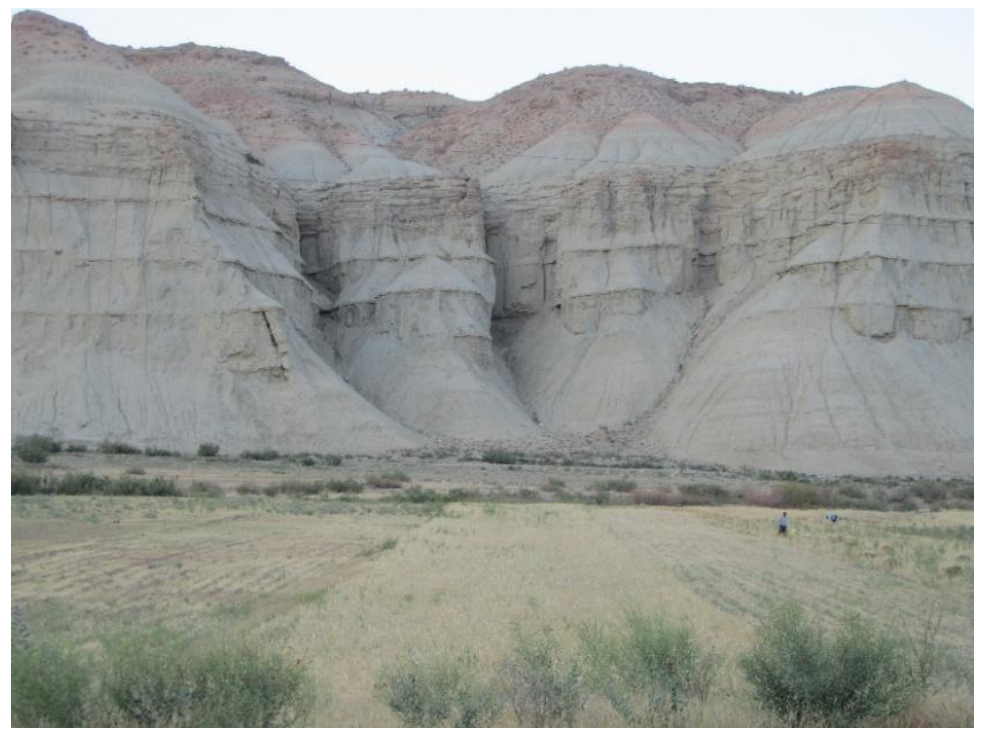

Figure 5. Drop down to Qala-ehchai River base

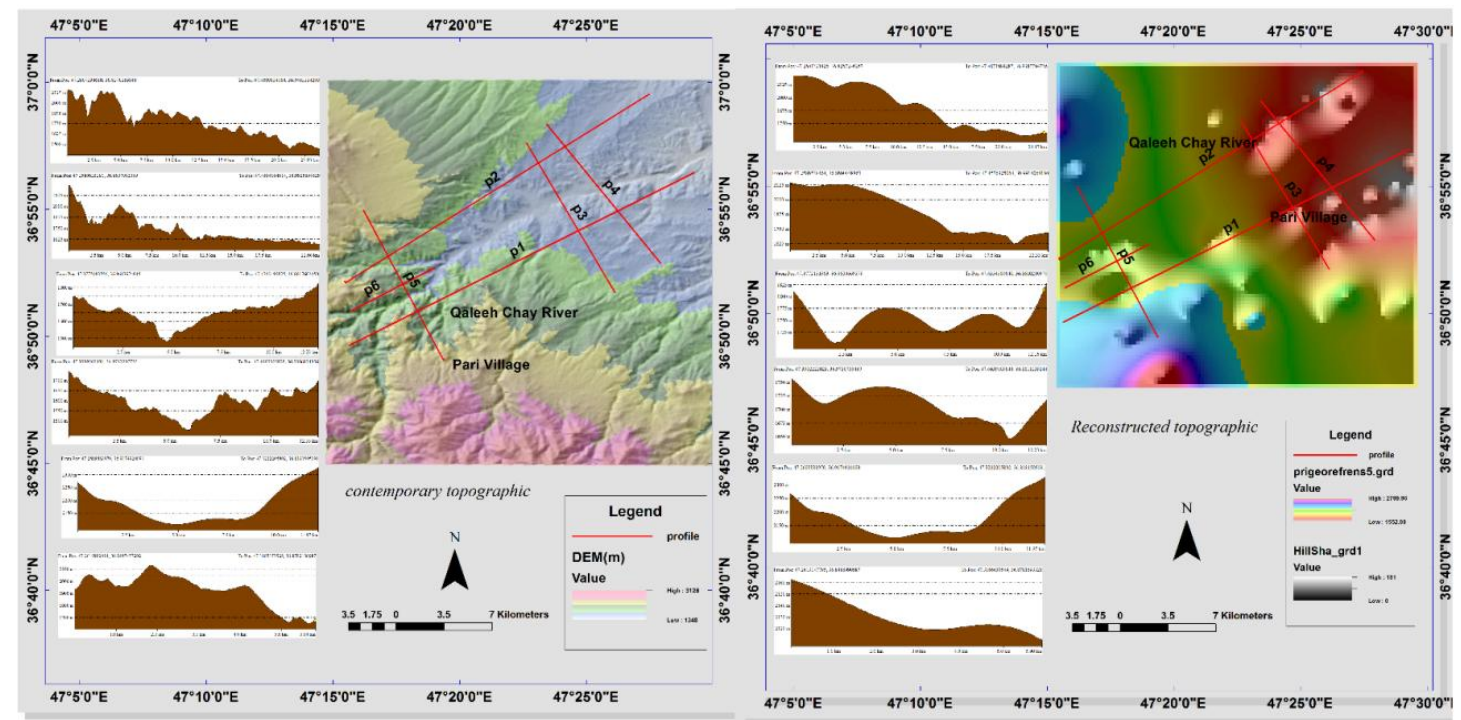

Figure 6. Location and schematic figure of profiles in the studied area in both quaternary and contemporary conditions

For further study of the reconstruction of the entire topography of the region, the height of these terraces was the basis of analysis and reconstruction of the total topography was done accordingly (Figs 7 and 8). An examination of the old terraces of the entire area during the quaternary topographic reconstruction suggests that the lake's conditions and closure of the area still retain their original status. In the drawn profiles, the average depth of erosion in profiles 1 to 6 was 140,115, 80, 225, 110 and $150 \mathrm{~m}$, respectively. Border of lake was also drawn assigning banks to each river. After simulating the topography of the quaternary, the previous profiles drawn on the topography were drawn on the reconstructed topography in the same direction. In this way, the altitude of eroded land levels was detected and quaternary lakes were reconstructed. 

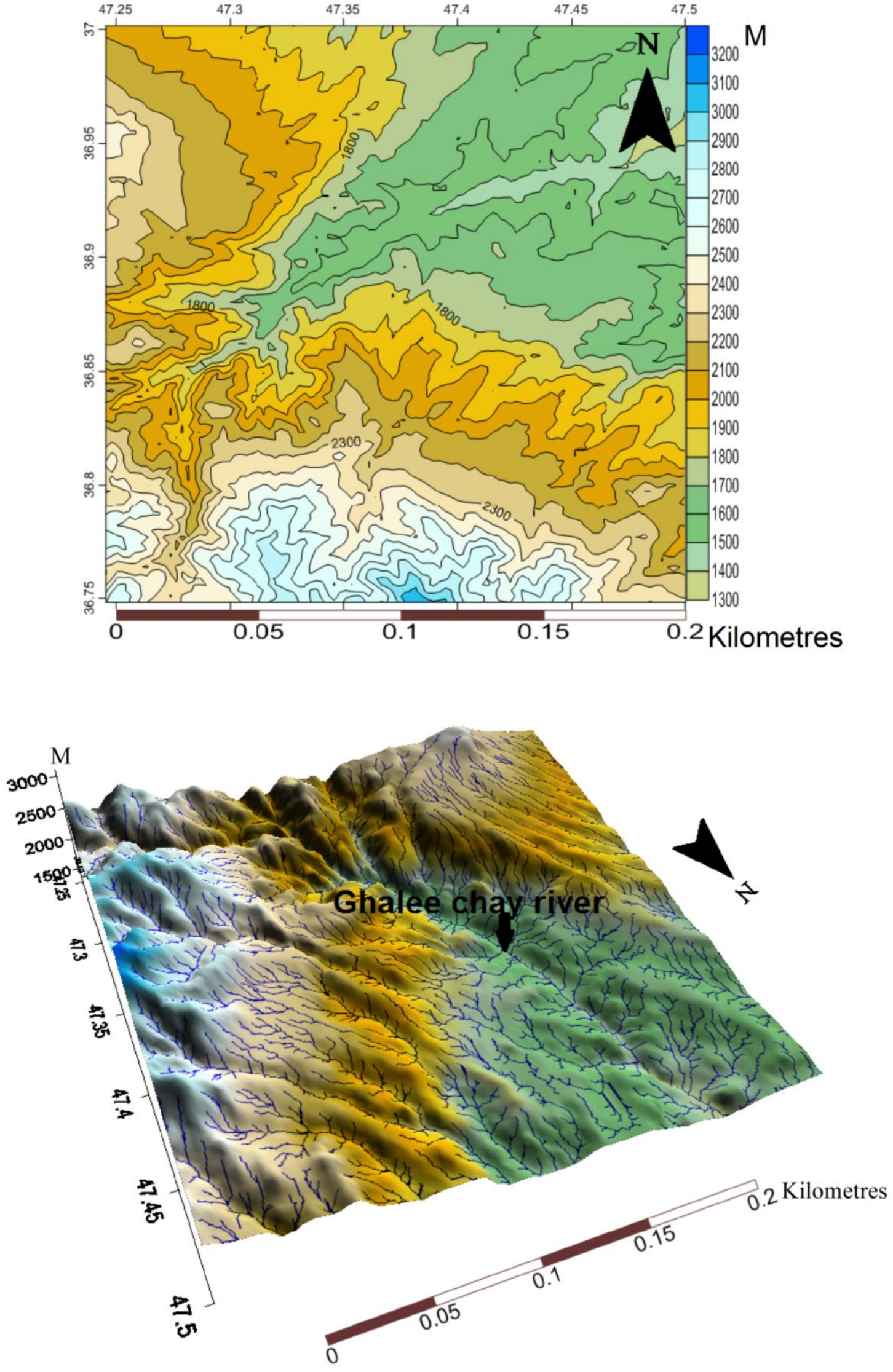

Figure 7. Contemporary topographic and 3D maps 

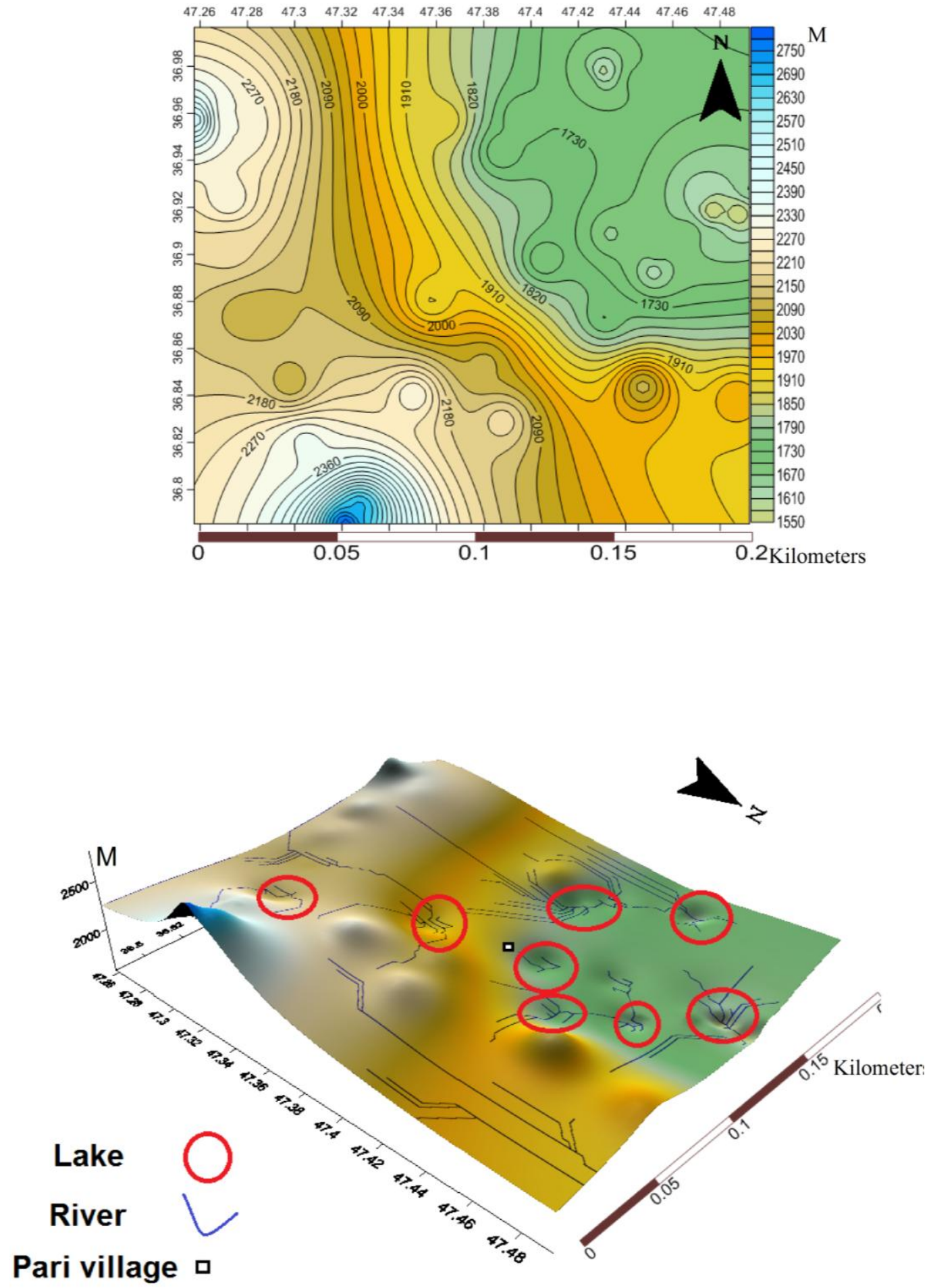

Figure 8. Reconstructed topographic and 3D maps

Given that the morphogenesis system in the quaternary was glacial and the study area was dominated by various lakes, it can be said that the glacial plates caused pouring erosion and created a number of lakes in one direction. The lakes have also been torn and drained on their left side. In the profile shown in Figure 7, this can be completely seen (Fig. 9). 


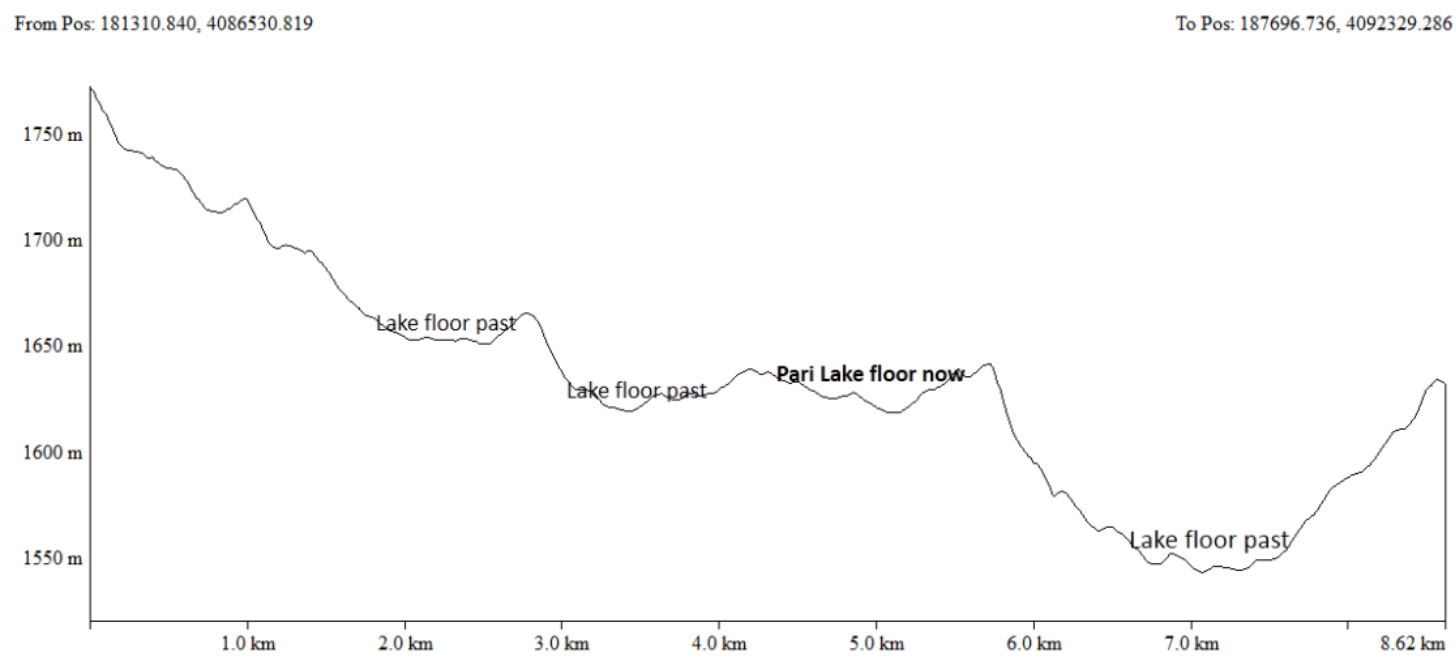

Figure 9. Transversal profile in the quaternary

\section{The granulometry of sediments}

Controlling slope over a long period of time in the plane causes exposure to air and physical and chemical weathering. The value of slope is also different in different bed rocks. This means that in a resistant formation, the slope undergoes fewer changes. In the study area, using a 30-meter DEM, a gradient map was obtained (Fig. 10). It turned out that the slopes of up to $5 \%$ are almost smooth and are considered as plain. On the direction map, the slopes of up to 5\% are called highlands. However, given that lakes have transformed from hole-like shape into a flat form over time, they indicate past lakes in the quaternary period. In addition to topographic maps, more environmental documentations, the best of which is granulometry of sediments, are required for proving that the area under study was a lake during the quaternary period. For this purpose, 14 specimens of sediment in 9 points with different geographical coordinates were transferred from the profiles to the laboratory environment (Fig. 11). After selection and initial washings, a specified amount of each specimen was weighed and granulometry started using a Shaker between sieves number 20 to 230. The remaining sediment in each sieve was weighed and the graph was finally plotted. Based on the location of the sediments, three samples were taken at different depths with respect to the apparent change of sediment type near Khandaghlo Lake, which is currently one of the lakes in the region; although it has become independent due to a change in the base level of Qala'ehchai River and the upstream basin waters are not naturally directed to the lake, part of the water of Qala'ehchai goes to its centre by creating an artificial pond and it is used for agricultural and fish farming purposes. Profiles 1, 2, 3 belong to sediment condition of this part of the basin. These profiles were used as control profiles for the analysis of other profiles because them granulometry indicates lagoon coastal sediments. The change in these three profiles indicates the uniform distribution of grains in different sieves, and more than $60 \%$ of the sediments remain in the sieves receiving the finer grains. In other areas, it was not possible to identify the exact river bank due to changes in the use of the rivers and the diversion of the rivers, but it was attempted take samples from the nearest potential bank (Fig. 12; Table 3). 
Table 3. Charts obtained from granulometric sediments

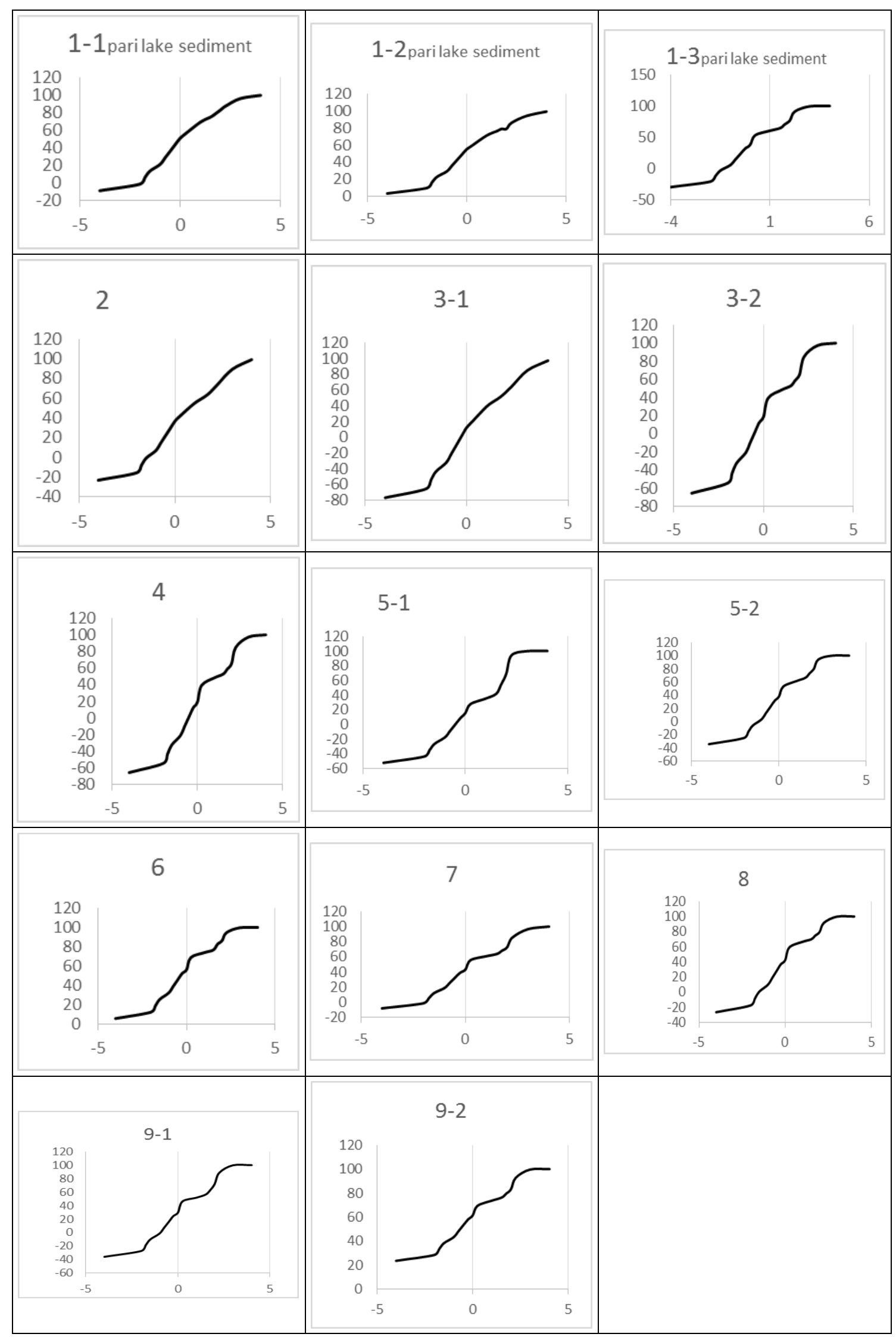




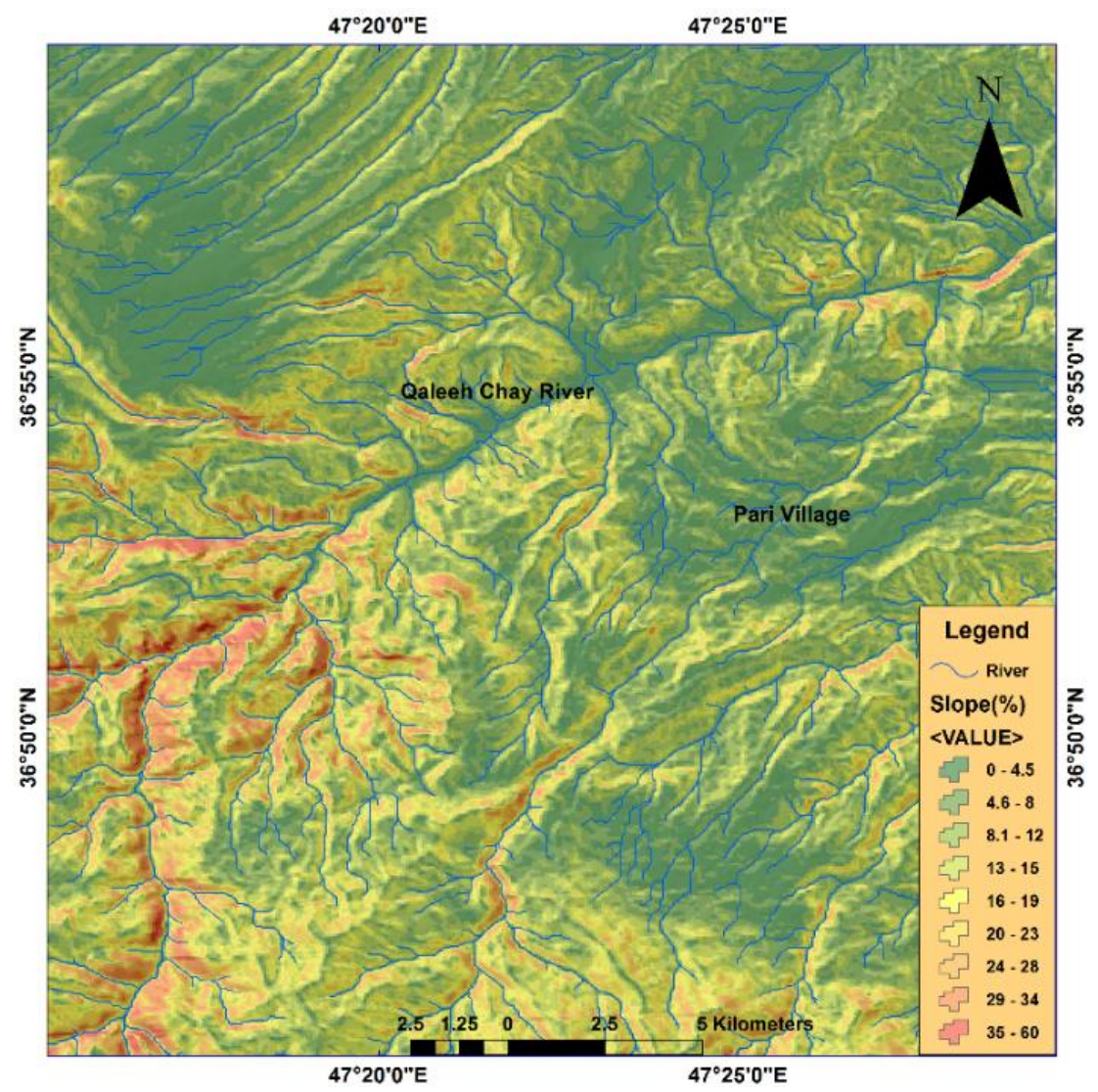

Figure 10. Slope map of the study area obtained from DEM with $30 \mathrm{~m}$ spatial resolution

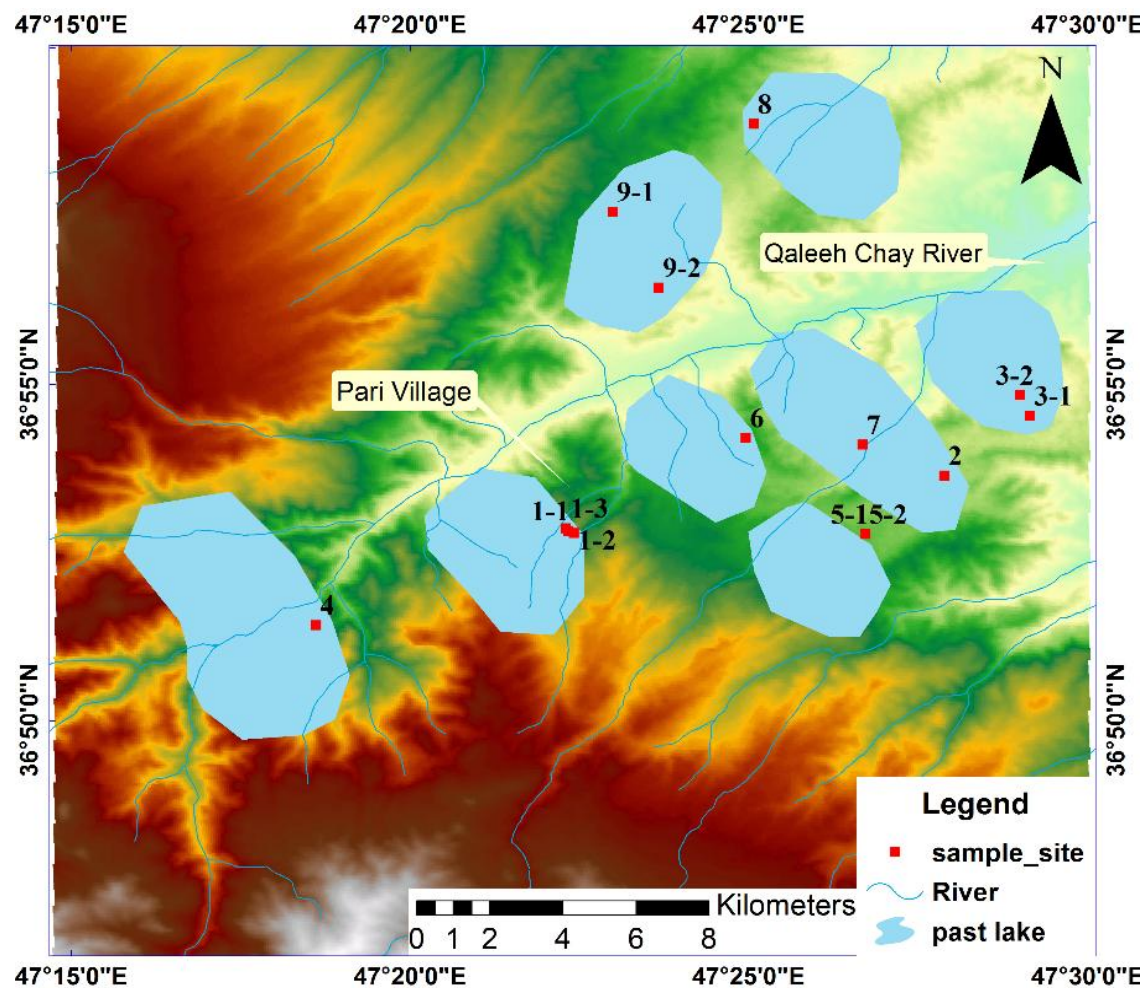

Figure 11. Location of sampling sites 
Profiles 1-3 and 2-3, taken from the same location with the farthest distance to the centre, are known as the Polygon of Lake and are very similar to the profiles provided by researchers such as Mahmoudi and Moghimi (2011) for glacier deposits, which is evidence that the area was a glacier during cold quaternary periods. Rest of the profiles $(4,5,6,7,8$, and 9) are affected by lake-glacier process, which indicates that the environment is affected by the glacier-lake process and that the polygon of the sediment lake shows a tendency to be glacier when being taken away from the centre.

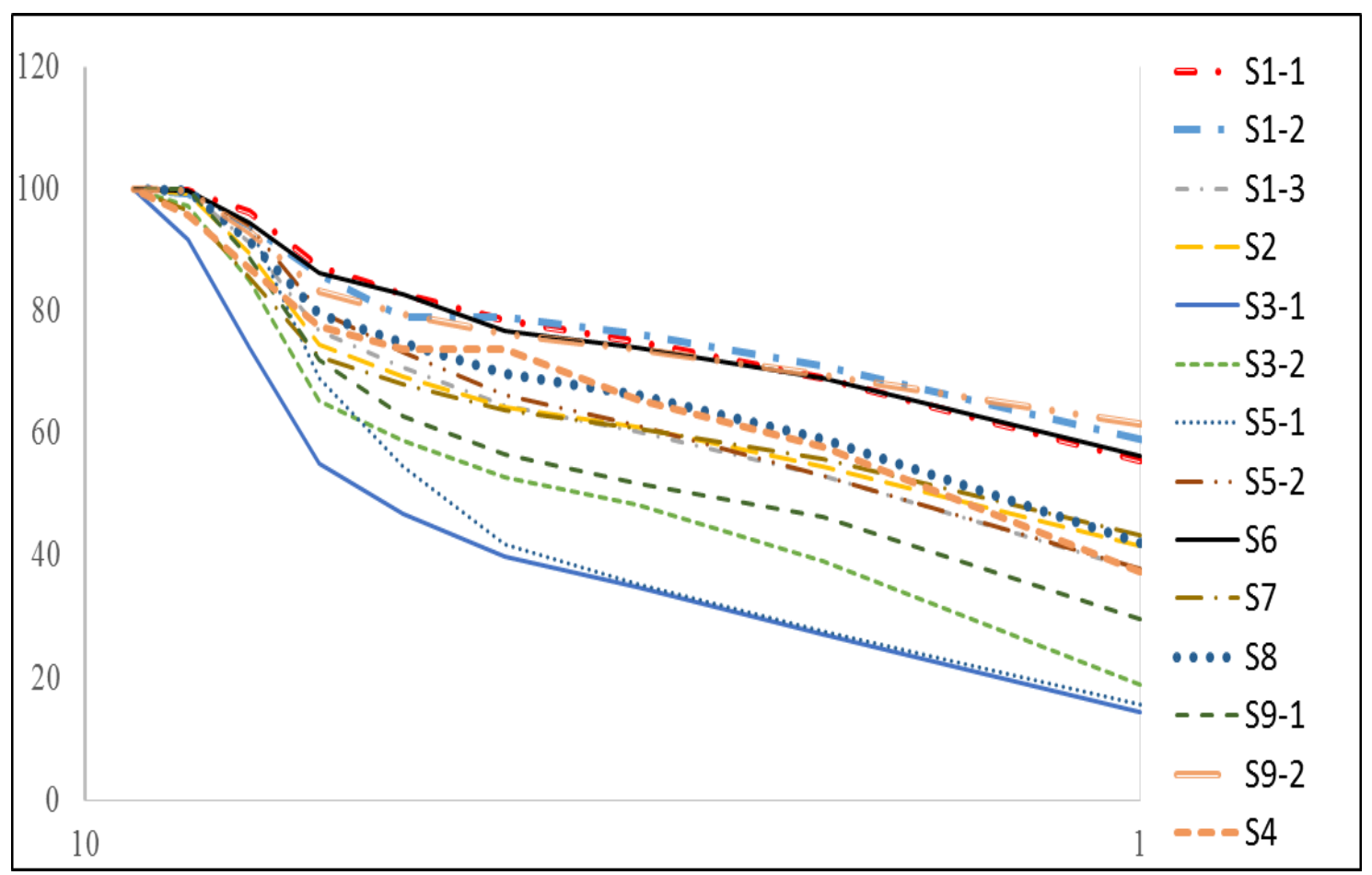

Figure 12. Plot of different sediment samples

The granulometric results of the data and the relationships in Table 1 show that, in terms of the $\mathrm{Mz}$ index, all samples are coarse grains and are divided into two groups of medium sand and coarse sand. In terms of Q1 index, the sediments fall into two very poorly sorted and poorly sorted groups, and only one sample has been moderately sorted. The Ski index subdivides the sediment into four groups. Most of the samples are located in the mediums positively skewed group of the fine particles. Two samples of asymmetric sediments are very positively skewed toward coarse particles and granularity. A large asymmetric sample is symmetrically skewed toward fine particles. In the $\mathrm{KG}$ index, the whole sediment sample was divided into two very platykurtic and leptokurtic groups. According to the data in Table 4, it can be said that most of the collected grains correspond to very slight differences with the precipitates taken from the Peri Lake. Accordingly, the condition of the lake is confirmed by past sampling sites.

The quaternary glacial processes of Iran have been exposed to various geographic and environmental conditions. Until now, moraines, U-shaped valleys, and cirques or mountain snow flats have attracted attention of many glacier researchers. Evidence of the quaternary glacial lakes was less considered. The topographic and geomorphological 
conditions of the Qala'ehchai Basin and the adjacent basins indicate that the streams flow out of the mountains to the plains in the wide and U- shaped valleys. U-shaped valleys were shaped due to the glacier flow in the quaternary cold periods. Investigating Qala'ehchai Basin as a typical basin on the west of the Ghezelowzan river from Mahneshan to Miyaneh shows that there is evidence of geomorphological effects of eight lakes from the quaternary period. Glacier lakes are not caused by the deposition of the terminal moraines or by the exploration of the glacier in the cirques, but rather they are formed by the glacier flow in marl sediments. Glacier flow in the marl sediments has created U-shaped valleys that have become independent basins, creating small and shallow lakes with the withdrawal of the glacier. By changing the base level of the Ghezelowzan River during the quaternary and overcoming the decreasing erosion on its branches, small basins have lost their independence and have been evacuated in Ghezelozen River. Several field surveys in different areas affected by the quaternary glacier in Iran indicate that the areas around the Qala'ehchai Basin are the only area that has kept the effects of glacial lakes. Studies of quaternary climate change in Khandaghlo Lake, as a remaining ecosystem since then, can be a nod to many quaternary issues.

Table 4. Computed grain size parameters and their verbal terms for outcrops from study areas

\begin{tabular}{c|c|c|c|c}
\hline $\begin{array}{c}\text { Sample and figure } \\
\text { number }\end{array}$ & Mean size (MZ) & Sorting (Q1) & Skewness (Ski) & Kurtesis (KG) \\
\hline $1-1$ & 0.3 coarse sand & 1.5 poorly sorted & $\begin{array}{c}2.266 \text { mediums } \\
\text { positively skewed }\end{array}$ & 0.2 very platykurtic \\
\hline $1-2$ & 0.17 coarse sand & $\begin{array}{c}2.015 \text { very poorly } \\
\text { sorted }\end{array}$ & $\begin{array}{c}1.19 \text { mediums } \\
\text { positively skewed }\end{array}$ & $\begin{array}{c}0.45 \text { very } \\
\text { platykurtic }\end{array}$ \\
\hline $1-3$ & 0.94 coarse sand & $\begin{array}{c}2.48 \text { very poorly } \\
\text { sorted }\end{array}$ & $\begin{array}{c}5.15 \text { mediums } \\
\text { positively skewed }\end{array}$ & $\begin{array}{c}0.63 \text { very } \\
\text { platykurtic }\end{array}$ \\
\hline 2 & 0.9 coarse sand & 1.57 poorly sorted & $\begin{array}{c}0.25 \text { symmetrical } \\
\text { skewed }\end{array}$ & $\begin{array}{c}0.65 \text { very } \\
\text { platykurtic }\end{array}$ \\
\hline $3-1$ & 1.43 medium sand & 1.14 poorly sorted & $\begin{array}{c}-1.1 \text { negatively } \\
\text { skewed }\end{array}$ & 0.70 platykurtic \\
\hline $3-2$ & 1.53 medium sand & 1.31 poorly sorted & $\begin{array}{c}0.657 \text { very } \\
\text { positively skewed }\end{array}$ & 0.72 platykurtic \\
\hline $5-1$ & 1.75 medium sand & 1.07 poorly sorted & $\begin{array}{c}0.58 \text { very positively } \\
\text { skewed }\end{array}$ & 0.69 platykurtic \\
\hline $5-2$ & 1.33 medium sand & 0.971 moderately & $\begin{array}{c}0.325 \text { very } \\
\text { positively skewed }\end{array}$ & 0.69 platykurtic \\
\hline 6 & 0.56 coarse sand & 1.125 poorly sorted & $\begin{array}{c}5.67 \text { mediums } \\
\text { positively skewed }\end{array}$ & $\begin{array}{c}0.43 \text { very } \\
\text { platykurtic }\end{array}$ \\
\hline 7 & 0.6 coarse sand & 1.8 poorly sorted & $\begin{array}{c}1.31 \text { mediums } \\
\text { positively skewed }\end{array}$ & 0.85 platykurtic \\
\hline $9-1$ & 0.37 coarse sand & 1.51 poorly sorted & $\begin{array}{c}2.17 \text { mediums } \\
\text { positively skewed }\end{array}$ & $\begin{array}{c}0.61 \text { very } \\
\text { platykurtic }\end{array}$ \\
\hline 0.71 coarse sand & 2.28 very poorly & $\begin{array}{c}2.75 \text { mediums } \\
\text { positively skewed }\end{array}$ & 0.68 platykurtic \\
\hline sorted & 0.83 coarse sand & 2.52 very poorly & $\begin{array}{c}1.87 \text { mediums } \\
\text { positively skewed }\end{array}$ & $\begin{array}{c}1.22 \text { mediums } \\
\text { platykurtic }\end{array}$ \\
\hline 1.33 lepokurtic \\
\hline
\end{tabular}




\section{Conclusion}

In the east of the western highlands of Zanjan Province, landforms are either closed or semi-closed basins. Their geomorphological evidence at first sight brings a land like the land of thousands of lakes in Finland to mind. Khandaghlo Lake is the only remaining lake in this region. In this area, where the altitude varies from 1600 to 1900 $\mathrm{m}$, there are convergence centres in the waterway network that are sometimes cut off from one side and water has been discharged. In order to have a standard profile, three sediment samples were taken at different depths from the lake bank; Granulometry of sediments indicate their homogeneous distribution. The snow-line height according to Wright, and Porter methods was 2357 and $2425 \mathrm{~m}$. If the highest snow-line height estimated by the Porter method is taken into account, it is noteworthy that all lakes are above the quaternary water and the ice equilibrium line since the height of the water and the ice equilibrium line is $1042 \mathrm{~m}$ below the snow-line height based on the findings. On this basis, the quaternary water and ice equilibrium line is less than $1400 \mathrm{~m}$, with the lower lakes with a height of nearly $1600 \mathrm{~m}$ above it. Field evidence and lithology of the region indicate that glaciers that are originated from high altitudes and well fed enter marl deposits by exiting the igneous area and resistant sediments. Glaciers in marl sediments create U-shaped valleys with a linear flow. They contribute to the creation of lakes in two ways: Lakes closest to the water and the ice equilibrium line have been established for the glacier valley terminal, such as the glacier and the terminal moraine. The rest of the lake has been created due to explorative erosion in long-tailed valleys as a result of further dredging of the lake bed. The granulometry of taking samples indicates that the profile of the sediments taken from the lake bank or its centre is more similar to the lake sediments, and their profile becomes of lake-glacial sediments by going away from the centre or bank of the lake. Of the $780,000 \mathrm{~m}^{2}$ of the total area of Qala'ehchai, about $96,000 \mathrm{~m}^{2}(12 \%)$ includes the identified 8 lake beds. Khandaghlo Lake, as an evidence of the lakes of the quaternary period, owes its existence to an artificial canal that transfers part of the water of the Qala'ehchai to the lake. With regard to climate change over the last few decades, the study of climate changes and quaternary ecological conditions has an important role to play in environmental planning. A detailed study of the climate change aspects of the region can provide important solutions for managing global warming. On the other hand, given the tourist boom, the introduction of these places is of particular importance in attracting tourists.

\section{REFERENCES}

[1] Abtahi, S. M. (2013): Investigation of paleoclimatology of Jajrood Basin in Iran by glacial evidence. - Geological Exploration of Desert Areas 1(1): 185-201.

[2] Amirahmadi, A. Maghsodi, A., Ahmadi, T. (2011): Evaluating the effects of quaternary glaciers on the lack of civilization and main urban habitation in Aspas plain. - UrbanRegional Studies and Research 3(10): 61-80.

[3] Askari Chawardi, H. (2009): Study of Quaternary Mountain Lakes in Jajrood Valley (Case Study: Hajiabad Area). - Master's Thesis, Islamic Azad Tehran University, Faculty of Literature and Humanities. 
[4] Bajracharya, S. R., Mool, P. (2009): Glaciers, glacial lakes and glacial lake outburst floods in the Mount Everest region, Nepal. - Annals of Glaciology 50(53): 81-86.

[5] Bao, H. Fairchild, I. J., Wynn, P. M., Spötl, C. (2009): Stretching the envelope of past surface environments: Neoproterozoic glacial lakes from Svalbard. - Science 2(323): $119-22$.

[6] Barr, I. D., Spagnolo, M. (2015): Understanding controls on cirque floor altitudes: insights from Kamchatka. - Geomorphology 248: 1-13.

[7] Bolch, T., Peters, J., Yegorov, A., Pradhan, B., Buchroithner, M., Blagoveshchensky, V. (2011a): Identification of potentially dangerous glacial lakes in the northern Tien Shan. Nat Hazards 59: 1691-1714.

[8] Bolch, T., Pieczonka, T., Benn, D. I. (2011b): Multi-decadal mass loss of glaciers in the Everest area (Nepal Himalaya) derived from stereo imagery. - The Cryosphere 5(2): 349358.

[9] Chinn, T. J., Whitehouse, I. E. (1980): Glacier Snow Line Variations in the Southern Alps. - Iahs-Aish Press, New Zealand.

[10] Cossart, E., Braucher, R., Fort, M., Bourlès, D. L., Carcaillet, J. (2008): Slope instability in relation to glacial debuttressing in alpine areas (Upper Durance catchment, southeastern France): evidence from field data and 10Be cosmic ray exposure ages. Geomorphology 95(1-2): 3-26.

[11] Derruau, M. (2011): Les forms du relief terrestre de geomorphology (translated by Mqsud, K.) - Tabriz University Press, Tabriz.

[12] Entezari, A. Amir Ahmadi, A. Ghandajik, A. Jahanfar, A., Shayan Yeganeh, A. K. (2015): Geomorphologic assessment of climatic changes of Gorganroud Basin in the quaternary. - Quaternary Iran 1(2): 169-180.

[13] Evans, I. S. (1977): World-wide variations in the direction and concentration of cirque and glacier aspects. - Geografiska Annaler: Series A, Physical Geography 59(3-4): 151175 .

[14] Evans, I. S. (1995): The form of glacial cirques in the English Lake District, Cumbria. Zeitschrift fur Geomorphologie NF 39: 175-202.

[15] Fujita, K. Sakai, A., Takenaka, S. Nuimura, T,. Surazakov, A. B. Sawagaki, T., Easuremen, T. (2013): Potential flood volume of Himalayan glacial lakes. - Hazards Earth Syst Sci (13): 1827-1839.

[16] Ghahroudi Taley, M. (2011): Estimation and comparison of the realm of permanent snow on the glacier and glacier Case study: Haraz Basin. - Geography and Development 9(25): 97-103.

[17] Ghiyas Abadi, M., Mousavi Nadushan, R., Fatemi, M. R., Jozi, S. A. (2014): Assessment of Gahar Lake Trophic Status using TLI Index. - Journal of Marine Science and Technology Research 8(4): 75-88.

[18] Glassera, N. F., Bennettb, M. R. (2004): Glacial erosional landforms: origins and significance for palaeoglaciology. - Progress in Physical Geography 28(11): 43-75.

[19] Gresswell, R. K. (1958): The Physical Geography of Glaciers and Glaciation. - Hulton Educational Publ., London.

[20] Jafari, G. H., Asghari Serkansrudi, S. (2014): The analysis of quaternary glacial effects of Zanjanrood. - Quantitative Geomorphology Researches 3(2): 16-30.

[21] Jananeh, C., Rajabi, M. (2016): The effects of the quaternary period in the seas and lakes of Iran. - 2nd International Congress of Earth Sciences and Urban Development 1-12.

[22] Jedari Eyvazi, J. (2013): Geomorphology of Iran. - Payame Noor University Press, Tehran.

[23] Kiani, T., Ramesht, M. H., Maleki, A., Safakish, F. (2016): Assessment and review the environmental risks resulting from climatic changes in Abarkooh Basin. - Geography and Development, Iranian 14(43): 19-34.

[24] Klinsley, D. B. (2009): The Deserts of Iran and Geomorphological Features and Its Paleoclimatology. - National Geographical Organization, Tehran. 
[25] Koinig, K. A., Shotyk, W., Lotter, A. F., Ohlendorf, C., Sturm, M. (2003): 9000 years of geochemical evolution of lithogenic major and trace elements in the sediment of an alpine lake-the role of climate, vegetation, and land-use history. - Journal of Paleolimnology 30(3): 307-320.

[26] Lewis, C. F. M., Anderson, T. W. (1989): Oscillations of levels and cool phases of the Laurentian Great Lakes caused by inflows from glacial Lakes Agassiz and BarlowOjibway. - Journal of Paleolimnology (2): 99-146.

[27] Longmore, M. E., Heijnis, H. (1999): Aridity in Australia: Pleistocene records of palaeo hydrological and palaeoecological change from the perched lake sediments of Fraser Island, Queensland, Australia. - Quaternary International (57): 35-47.

[28] Mahmoudi, F., Moghimi, E. (2011): Research Method in Physical Geography (Geomorphology). - Gomes Press, Tehran.

[29] Martin, J. Head, Ph. G. and Amos, S. (2008): The quaternary: its character and definition. - Episodes 31(2): 234-238.

[30] Nabavi, H. (1976): A Preface to the Geology of Iran. - Atomic Advocates of the Geological Survey, Tehran.

[31] Obinegbu, I. R., Chiaghanam, O. I., Chiadikobi, K. C (2013): Paleoenvironmental indications from textural parameters: a case study of the Paleocene to Eocene sandstones in some parts of Anambra Basin, South-Eastern, Nigeria. - International Journal of Scientific \& Technology Research 2(10): 201-213.

[32] Olvmo, M., Johansson, M. (2002): The significance of rock structure, lithology and preglacial deep weathering for the shape of intermediate-scale glacial erosional landform. Earth Surf, Process Landforms (27): 251-268.

[33] Oskooi, B., Omidian, S. (2013): Evaluation of Havir Lake formation causes based on magnetotelluric data. - Earth and Space Physics 39(2): 95-110.

[34] Parizi, I. Taqian, A., Ramsht, M. H. (2013): Evidence of the quaternary glaciers in the Tiguani Basin of Sirjan. - Quantitative Geomorphology Research 2(3): 111-128.

[35] Ramesht, M. H. (2001): Glacier Works in Zefareh, Isfahan. - Research Project No. 800305, Research Council of Isfahan University.

[36] Ramesht, M. H. (2004): The fourth glaciers in the suburbs of Isfahan. - The Growth of Geography Education 19(67): 22-10.

[37] Ramesht, M. H. (2013): Symbols and Images in Geomorphology. - SAMT Press, Tehran.

[38] Rezvani, M. R., Ramezanzadeh, L. M., Mohammadpour, J. M. (2010): The analysis of socio-economic effects of industrial areas on developing rural areas (case study: industrial area of Soleiman Abad, Tonekabon). - Geography and Development, Iranian 8(18): 6992.

[39] Russell, C. (1889): Quaternary History of Mono Valle. - US Government Printing Office 1889 - Geology, Strati-Graphic, California.

[40] Seif, A., Abtahi, S. M. (2013): A survey of climatic Changes of Namak Lake Basin in the late quaternary. - Geography and Planning 17(46): 91-111.

[41] Seif, A., Ebrahimi, B. (2014): Combined use of GIS and experimental functions for the morphometric study of glacial cirques, Zardkuh Mountain, Iran. - Quaternary International (3): 1-14.

[42] Shamsipour, A,. Bagheri, S. Shokri, S. Jafari Aghdam, M., Salimimanesh, J. (2015): Reconstruction of the last glacial snow lines by the evidences of glacial periods in North West Zagros (Case study: Anticline Qalajeh). - Geography and Development, Iranian 13(39): 61-74.

[43] Sundal, A. V. Shepherd, A. Nienow, P. Hanna, E. Palmer, B., Huybrecht, P. (2009): Evolution of supra-glacial lakes across the Greenland Ice Sheet. - Remote Sensing of Environment (113): 2164-2171.

[44] Tahoni, P. (2004): Geomorphological evidences of Pleistocene glacial erosion in Talesh Mountain. - Geosciences Researches 36(1): 55-31. 
[45] Velayati, S. A. (1995): Geography of Water and Water Resources Management. Khorasan Press, Mashhad.

[46] Walter Goldthwaite, J. (1908): A reconstruction of water planes of the extinct glacial lakes in the Lake Michigan Basin. - The Journal of Geology 16(5): 459-476.

[47] Ward, W. C. (1957): Brazos River bar: A study in the significance of grain-size parameters. - Journal of Sedimentary Petrology (27): 3-26.

[48] Yamani, M. Jiadari Ayvazi, J., Abolghasem, G. (2007): Geomorphologic evidences of glacier borders in the Karkas Domain. - Modarres of Humanities 11(1): 207-228.

[49] Zomorodiyan, M. J. (2012): Geomorphology of Iran. - Ferdowsi University, Mashhad. 